\title{
Judaism and Interreligious Co-evolution: A Retrospective Reading
}

\section{Alon Goshen-Gottstein ${ }^{1}$}

Published online: 7 May 2020

(C) Springer Nature B.V. 2020

\begin{abstract}
This introductory essay is my attempt to offer a reading of the corpus that provides the basis for the essays in the present issue of Contemporary Jewry. The books that form the basis for reflections divide into two categories-collaborative interfaith projects and studies in Jewish theology of religions. Beyond this division, I identify a common approach that is theologically informed and that sees religions as evolving entities that reach toward fulfillment of their higher purpose. I propose application of the term "coevolution," drawn from the field of biology and evolutionary theory but increasingly applied to the social sciences, as a means of describing the interdependence between religions. My application considers coevolution to be purposeful toward a higher goal. In this light, advances in interreligious understanding, collaboration, and theology all contribute not only to a more peaceful society but also to the actual growth in religions toward their own stated spiritual ideals and goals.
\end{abstract}

Keywords Coevolution $\cdot$ Interreligious dialogue $\cdot$ Judaism $\cdot$ Religions

\section{Introduction}

The present issue of Contemporary Jewry devoted to Judaism and world religions is centered around my (mostly) published work. Authors in this collection have been asked to review a series of publications that tackle the issue of Judaism and world religions from various perspectives: collaborative think tank projects that bring together scholars of different religions to think through common challenges, edited volumes that explore issues of Jewish theology of religions, and monographs that explore important dimensions of Jewish views of other religions. I have been blessed to publish over a dozen volumes that explore these issues, and several others are in press or in preparation.

Alon Goshen-Gottstein

gogo@elijah-interfaith.org

1 The Elijah Interfaith Institute, Jerusalem, Israel 
I owe a great debt of gratitude to Haviva Pedaya, who offered to host a conference in my honor when I turned 60. In response to this kind offer, I let her know that rather than lectures given "in my honor," I much prefer presentations that engage my work. This eventually led to several sessions devoted to Judaism and World Religions, that took place in the framework of the seventeenth World Congress of Jewish Studies, in dialogue with my work. As things turned out, Harriet Hartman, editor of Contemporary Jewry, got word of this series of discussions and considered it worthy of the attention of Contemporary Jewry's readership. After all, the question of Judaism's relationships with other religions is an important, and much overlooked, aspect of contemporary Jewish reality, affecting thought currents, social movements, and individual life journeys. She therefore asked me if I would be willing to continue the conversations that began at the World Congress of Jewish Studies in the pages of Contemporary Jewry by serving as guest editor of an issue that would build on those conversations. The concept was to use each of the reviews that discussed one of my books as a launchpad for a broader discussion that would explore some aspect of Judaism's relationship with other religions and how it plays out in contemporary social reality and present-day thought.

The format was anomalous and, to a certain extent, so was the work of the editor. The essays envisioned for the journal were not pure book reviews nor were they original research pieces. They were a cross between a review, a statement of contemporary thought, and an analysis of some aspect of present-day reality and the challenges it poses to Judaism. Given such an original format and considering the many ways in which the task could be carried out, it is no surprise that different authors implemented these guidelines in various ways. This itself lends our volume a breadth and variety that may exceed the customary parameters of the host journal. No less anomalous is the choice of the editor. Sitting through multiple sessions devoted to one's academic and theological work is one thing; serving as editor for pieces analyzing one's own is quite another. This has been uncomfortable for me on many occasions, and I am thankful to Harriet's continuing support and encouragement. That many of the essays are not only appreciative but also critical is a type of academic-spiritual joy.

\section{Toward a Retrospective Self-awareness}

The particularity of the present issue of the journal necessitates some broader framing. My attempt to author a lead essay has turned out to be extremely important for me in terms of taking stock and gaining perspective on my own work. Certain things became apparent to me only as I gathered my thoughts to prepare the present introductory essay. In the process I came to understand something about my own vision, one might almost say my mission, as this concerns Judaism in relation to world religions. Given that the present issue is so closely associated with my person, I have decided to go "all the way" in this essay, and not only to describe my oeuvre to date as background to these essays, but to offer a reading, an interpretation, a way of making sense of the ensemble of publications surveyed here as well as some that are still underway. This retrospective 
appreciation, the discovery of what seems to me to be the core drive and the particular vision that informs my work, is relevant not only to understanding whatever my unique voice might be within the broader horizon of Jewish thought and theology. It is, I believe, also a statement of an approach to Judaism today, its needs, and its path to growth in the future. While each of the essays explores some dimension that is of concern to the study of contemporary Jewish life, the attempt to offer a comprehensive reading of my own work to date is, I believe, itself a further contribution and therefore goes to the heart of the concerns of the journal. My gratitude to its editor is therefore all the deeper for enabling a process of self-understanding of what has been my attempted contribution to Judaism and its present-day vitality.

I would like to begin by sharing the insight to which I came in identifying the common thread that runs through my work and then describe the individual projects in light of this insight. My own theoretical work grows out of my practical work in the field of interreligious relations. More than twenty years have passed since I founded in Jerusalem the Elijah School for the Study of Wisdom in World Religions, later renamed the Elijah Interfaith Institute. The initial focus of the Elijah School was the teaching of religions and advancing interfaith understanding to theological students, primarily those affiliated with a founding consortium of 13 Jewish, Christian, and Muslim students. While participants soon included theological students from leading North American institutions, especially through a partnership with McGill University's Faculty of Religious Studies, the focus on teaching students of religion and theology was constant for the school's first six years. The challenges of introducing students to other religions opened up very early to the field of Theology of Religions and the need for each religion to account for other religions in terms of its own theological worldview. Thus, interfaith study led to a related field of studytheology of religions - the first facing outwards to the religious other in a movement of understanding and collaboration, the second facing inwards to a tradition's own views of the religious other.

Since those early days, my own theoretical interests have taken this twofold approach: interfaith collaboration, especially educational, theological and reflective, and ongoing consideration of Jewish views of other religions. This dual interest continues to inform my research and reflection agenda till this day, more than twenty years later. While most of my public activities through the Elijah Interfaith Institute would be classified under the rubric of interfaith engagement-bringing leaders and scholars of different religions together in order to increase understanding and lay foundations for practical collaboration-some of the public activities also express the particularly Jewish concerns of a Jewish view of other religions. These include public condemnation, action, and education following instances of violence to members of other faiths and their institutions carried out in the name of Jewish religion.

This two-pronged approach to other religions describes the corpus of work I have been blessed to create. It divides between works that bring together voices of different religions in a collaborative conversation, where Judaism occupies only one seat at a common table, and works that focus specifically on Judaism and its relations to other religions, either directly or through examination of the very categories through which Judaism has traditionally thought of other religions. 
For many years I had considered that my intellectual efforts contribute to two distinct fields. My work in theology of religions contributes to the field of Jewish thought and Jewish theology, and the work I have facilitated in which scholars and theologians of multiple religions have taken part contributed to the emerging field of interfaith studies. It is only as I sought to offer a reading of how my work can be presented, especially in a context of contemporary Judaism, that a synthetic reading emerged that ties my entire oeuvre together as part of a larger project and a specific perspective from which to understand Judaism.

The insight is simple. Judaism is to be appreciated, understood, and cultivated within the broader framework of world religions. This is, of course, no novelty. From its inception, Judaism positioned itself over and against other religions, staking its own ground and affirming its own particular identity. For the greater part of its history, Judaism has viewed itself over and against other religions through an oppositional lens. The core insight that runs through my work is that Judaism and other faiths must grow together. Rather than the oppositional framework by means of which Jewish identity and particularity are affirmed, we must consider Judaism as a member of a larger class of religions, all of which share in common more than what divides them, and all of which share in a fundamentally similar quest for attaining spiritual heights, advancement of the individual in his or her spiritual life, and the ordering and improvement of society. While the differences should not be minimized and while there is great value in appreciating the particularity of Judaism and what it has to bring to the world at large and to other religions in particular, this perspective should not be the exclusive lens through which Judaism is viewed in the broader context of world religions. Such exclusive perspective seeks to affirm Jewish superiority and to downplay the value of other religions, and it effectively blocks out the possibility of inspiration, learning, and enrichment across religious lines, in a movement of common advancement toward the goals shared by all major faith traditions. The present moment in time allows us to redefine relations between religions. Advances in interfaith relations, the recognized need for collaboration and partnering between religions in their battle against common enemies in society, rather than against each other, and the need and opportunities for better appreciation and understanding of the religious other in an increasingly smaller and better informed world all indicate a paradigm shift, or the potential for such a shift, in how religions view each other. The implication of such a paradigm shift, moving from competition to collaboration, from ignorance to better understanding, and from attitudes of othering to appreciation of a common humanity, grounded in its spiritual and even divine roots, is that one's own religion can no longer be appreciated only in oppositional terms over and against another religion but must be understood within the framework of the common enterprise and journey of all religions.

Such a perspective is informed by a teleological view of religion. Religions are instruments of evolution. Both the individual and society are guided to greater perfection by means of religion. Perfection consists of moral ordering of society, the moral, intellectual, and spiritual advancement of the individual, and the gradual and eventual advancement of human consciousness toward its spiritual and divine roots. Fundamentally, all religions engage in this common project. All religions are instruments of growth, individual and societal. Moreover, religions themselves are in the 
process of growth. Over time, the teachings and practices of all religions advance in a movement of progress toward higher perfection associated with God and the spiritual life. It is therefore not only that all religions engage in a common educational project. They also partake of a common journey toward the goal of their own perfection, in line with their founding vision or their highest spiritual aspirations, as articulated by the finest exemplars of the traditions.

This perspective allows us to redefine Judaism in relation to other religions. If all religions are engaged in a common growth-related project, then Judaism must be appreciated in light of this basic commonality. Judaism and other religions fundamentally do the same thing, and if so, they should be appreciated in light of this recognition. More fundamentally, as is true of other aspects of society and its diverse manifestations, ultimately the growth of all religions must occur jointly, or at least interdependently. Spiritual growth and evolution are a matter for all and must at some point be recognized as the common enterprise of all religions.

This opens up a new perspective for appreciating Judaism. If for the greater part of its history its self-understanding was conditioned by an oppositional view that profiled difference and affirmed superiority, the view proposed here serves as a corrective to this prevailing tendency. It is not that Judaism is the same as other religions nor that its particularity and unique message, however they may be construed, is lost. But these must be stated, affirmed, or discovered within the fundamental commonality of growth, progress, and evolution that is the common lot of all religions.

The view set forth here is in many ways intuitive. In the same way that we have come to recognize the fundamental commonality of humanity despite differences of race (and later of gender), we can come to the recognition of a common backbone that provides the basic structure for all religions, with differences, significant as they may be, being superimpositions upon this fundamental commonality. Still, in the same way that racial and other forms of equality (not identity) had to be fought for, socially and ideologically, the understanding of how Judaism as viewed within, rather than over and against, other religions is a position that must be constructed and justified. The work of its justification is complex and multi-faceted.

As I consider my own work, I realize that all of it can be accounted for within this conceptual matrix, and all of it can be seen in some way as contributing to the project of viewing Judaism as part of the broader movement of religions seeking perfection for themselves and for their adherents. The work of justification involves identifying precedents, legitimating a view of Judaism that is collaboratively based, revisiting ideas that have served as foundations for an oppositional and exclusivist view, establishing paradigms for positive appreciation of and possible receptivity from other religions, and opening up the field of Jewish relations to other religions to a fresh discussion. This accounts for much of what I have done.

Much of my contribution to this agenda has taken the form of facilitating a conversation within the Jewish community by means of which ideas could be aired, new possibilities could be put forth, and a critical and constructive spirit could come together in service of developing a new agenda. About half my work has taken the form of facilitating conversations among others, both among Jews and across religious lines. In my role as editor I have also had the possibility to consider what 
statement a project makes as a whole. My editor's voice has allowed me to take the work of individual scholars and to suggest how it might amount to a statement that is larger than the sum of its parts and how such a statement advances a broader spiritual vision, such as the one spelled out above. Thus, gradually the contours and message of my own work emerge through my own voice as an author, the projects I have initiated, and my voice as an editor.

Two points follow that may help in contextualizing my approach. The first has to do with how religions are portrayed. My view of religion, all religions, is unabashedly theological. Religions are complex entities, spanning millennia, exhibiting multiple and conflicting facets of human behavior, and bringing under one roof the finest of human behavior along with the worst. An internal theological view of Judaism would not content itself with a sociological or historical presentation in which, for example, the history of Jewish mafia is given the same weight as the history of prophecy. Our narratives are informed by certain value propositions. Descriptions, even supposedly neutral historical definitions, betray some ideals and values in light of which they present data cast as purposeful, meaningful, and coherent. A theological view of Judaism as a progression of a religion across history, in a process of evolution, growth, purification, and quest for its ultimate goal is a common structure, even if variously portrayed. Theologically, there is no problem in offering a reading of Judaism in history in teleological terms that of necessity privilege and profile some aspects of the religion or the life of the religious community over and against another. That is part of meaning-making and storytelling in the light of faith.

My own suggestion that all religions be read along the lines of the spiritual evolution that we are comfortable applying to Judaism can similarly not be seen as purely descriptive. It is theologically and teleologically motivated in the same way that describing Judaism in these terms is. Such an approach can likely be accounted for by a combination of several factors: (a) taking seriously the implications of growth of interfaith as a reality that reshapes relations between faiths; (b) an unbiased study of other religions, or the best in them, in a way that makes the extension of such a teleological view to other religions a matter of intellectual honesty; and (c) the positive appreciation of other religions based on elevating and transformative experiences with individuals or dimensions of those religions. Some combination of the experiential and the theoretical informs my willingness to approach all religions with an empirically-based view that goes beyond the descriptive and adopts a teleological, and hence theological, view of those religions. In short, my theology of religions leads me to view other religions as part of the fundamental theological structures and processes through which I view my Judaism.

A second theoretical statement that might allow the reader to better understand the conceptual framework from which my work can be appreciated is drawn from an altogether different domain - biology. As the thesis spelled out above dawned on me, I sought analogies with which to put into words the recognition that religions are interdependent in the processes of growth in which they are engaged and that are constitutive of their very being. I had the intuition that biology might provide a term that would allow me to describe the dynamics of how I view religions. A close friend, Sarah Halevi, a biologist by training, was helpful in pointing me toward a term with significant currency in biology-coevolution. I do not presume at the time 
this is written to fully grasp the significance of the analogy, and I consider it an invitation to myself to deepen reflection on the notion and its usefulness for understanding relations between religions. But even an initial popular definition suggests its usefulness to the present attempt to find a language by means of which to project a positive view of Judaism and other religions in teleological, growth-oriented terms. A succinct definition is that coevolution is the process by which two or more species evolve in tandem by exerting selection pressures on each other (Coevolution n.d). ${ }^{1}$ Evolution, then, is the name of the game. It applies to differences but ties together different species to a common process that is ultimately greater than the particularity of these species. If coevolution is an important force in bringing about transitions, the same can be said of interactions between religions, which bring about growth in each of the religions that interact with one other, even under stressful conditions. Pressure - selective pressure for the biologist-is essential to the evolutionary movement, a fact that can readily be transposed to historical, and even contemporary, relations between religions. Pressure, competition, and the like may be the day-to-day experience, even when a larger story of common evolution is unfolding through such pressures. Multiple forms of coevolution suggest there is no one form through which it is expressed, any more than there is only one form that governs the intertwined history of two religious communities.

Coevolution is primarily a biological concept, but researchers have applied it by analogy to other fields. Consider Henrik Valeur's application of the concept to urban architectural design: "As we become more and more interconnected and interdependent, human development is no longer a matter of the evolution of individual groups of people but rather a matter of the coevolution of all people" (Valeur 2014, 22). Relations of state and religion have also been described in terms of coevolution. Jeremy Menchik (2016) describes the relationship between Islam and democracy in Indonesia in terms of coevolution. The contours of religion and state are fluid and they develop in interdependency. Although the state shapes religion, religion, in turn, also shapes the state. There is thus a mutual and inevitable entanglement of state and religion that Menchik describes in terms of coevolution. Similarly, Robert Bianchi (2019) has studied the encounter between China and the Islamic world, which he describes in terms of coevolution. ${ }^{2}$

One final author who has considered relations between cultures-in fact, between religions - in terms of coevolution is Lloyd Burton. His Worship and Wilderness: Culture, Religion, and Law in Public Lands Management (Burton 2002) applies the notion of coevolution to the study of spirituality and the relations of indigenous American people to other spiritual traditions and movements. In the framework of methodological reflections on his work, he offers further clarification on his use of coevolution to describe relations between cultures and spiritual traditions:

\footnotetext{
1 A succinct introduction to coevolution in biology can be found in Ehrlich (1986, 3-6).

2 See, in particular Bianchi (2019, 127-129), where Bianchi describes a range of encounters between Muslims and Chinese, as illustration of coevolution.
} 
"Coevolution" is a concept borrowed from the biological science of ecology. What it refers to is how two or more species of plants or animals inhabiting the same ecosystem coevolve in response to each other's behavior. The term itself is divisible into relationships described as examples of either adversarialism or mutualism. Adversarialism refers to situations such as a prey species developing through evolutionary means various defense mechanisms (e.g., noxious exudations or camouflage coloration) to ward off threats to its survival from one or more predator species. Predator species may then, in turn, develop some structural or behavioral means of circumventing these defenses. By contrast, mutualism refers to coevolutionary changes among two or more subject species by which they change in ways that actually enhance the effectiveness of each other's survival strategies; that is, they evolve toward higher levels of cooperation. (Burton 2005, 713)

Burton goes on to illustrate these different types of relationships through expressions of cultural responses in North America to the question of spirituality and the environment. $^{3}$

Extending coevolution to the realm of religion is therefore not a novelty. I do, however, have to state where my approach departs from that of the biological use of the term, and even from its further extension into the political-cultural-religious, as this finds expression in the works cited above. Evolution theory is not purposeful. It does not assume some inherent telos. Evolution is adaptation, not progress. The same is likely true for the applications of coevolution to various expressions of human behavior. ${ }^{4}$

By contrast, my own view, as stated above, is theological and teleological. My use of "evolution" and, by extension, "coevolution" is not neutral, blind, or descriptive. It is purposeful and assumes evolution and growth toward a particular goal and perspective understood in relation to God and higher spiritual ideals. It would seem that in this matter I am a disciple of Rabbi Abraham Isaac Kook, who already at the end of the 19th century accepted evolutionary theory but cast it in positivist terms and within a teleological and God-oriented framework (see Feit 2006; Cherry 2003). What Rav Kook did with physical evolutionary theory, I seem to be doing with its extension- coevolutionary theory. I leave it to others to debate the justification or the merits of such an approach. For present purposes, it is sufficient to appeal to coevolution as an analogy to an approach to religions that would position Judaism and world religions in a particular way. In this approach, Judaism and world

\footnotetext{
${ }^{3}$ In the field of religion, one might profitably apply the notion of coevolution to the studies of Daniel Boyarin regarding the mutual and interdependent formation of Judaism and Christianity (see, for example, Boyarin 2004).

4 Actually, this point may be queried. Both Menchik's (2016) description of Indonesia and Bianchi's (2019) description of China may not be totally value-free. The growth of tolerance in Indonesia is seen as positive, as is the growing capacity of the Chinese to listen and adapt to Muslim partners. Burton's description of the greening of faith of Judeo-Christian scholars could similarly be read in positive value terms. Could it be, then, that evaluation is inseparable from the application of coevolution to the human realm? I leave this query in the notes because such valuation is at most implied and is never articulated by these authors as a fundamental aspect of the processes described.
} 
religions are appreciated in terms of purposeful growth that leads them all, independently and interdependently, to states of greater spiritual perfection and closer to their goals as instruments for God, his knowledge, and his purposes.

\section{An Overview of Publications from a Coevolutionary Perspective}

Based on this broad statement of how the message of my work can be construed, I would like to present the different projects, especially those reviewed in the present issue, as building blocks for the construction of this conceptual edifice. As it turns out, many of the thematic contributions that constitute these building blocks can be presented in pairs, where one key idea is expressed in two complementary works. I will therefore present the works in pairs, grouping them thematically and programmatically.

\section{Modelling Religion: Considering Religious Personalities}

The view of Judaism as part of the larger community of world religions and the possibilities this holds for spiritual growth and evolution finds its most developed expression in Religious Genius: Appreciating Inspiring Individuals Across Traditions (Goshen-Gottstein 2017). The book, though authored by me, is in fact the outcome of a research project that involved up to 50 scholars from all religions. Its methodology was, from the outset, one of advancing a spiritual-theological agenda in a collaborative manner and so was its subject matter. The project and the book that resulted from it sought to identify ways of appreciating and being inspired by the finest exemplars of religions and how they can inspire not only members of their own tradition but also members of other traditions. Judaism was well represented in the project, not only by my own involvement but also by the engagement of half a dozen scholars, theoreticians of religion, and historians of Jewish thought. However, the point of the project was not to feature one religion or extol its exemplary figures. The point was to develop a common conceptual framework by means of which we could recognize, appreciate, and receive inspiration from such individuals across religious lines. The category that was developed is "Religious Genius." The book is devoted to constructing the category and stating its advantages compared to more conventional categories, primarily saints. It sets forth a model of what constitutes a Religious Genius - a series of qualities that make these individuals stand out significantly above other expressions of religious excellence within their traditions. The model serves as a means of recognizing the special stature of these individuals, enhancing their attractiveness, and justifying the possibility of receiving inspiration from these individuals. One of the chapters of the book argues that one dimension of what makes a Religious Genius is the ability to inspire across religions. Recent examples of great teachers (whether or not they fit the model fully) suggest we are increasingly seeing teachers, religious exemplars, and sources of religious inspiration who include the interreligious dimension as part of their teaching. 
The interreligious dimension is thus germane, or has great potential, when it comes to the notion of "Religious Genius."

One of the challenges of this particular project, and indeed, of the broader project of situating Judaism amidst other religions in a movement of coevolution, is the relationship between the universal and the particular-that which is common to religions and their particularity. The "Religious Genius" model assumes commonality of spiritual experience and being, despite diversity of theology, religious practice, and all the stuff that gives religion its fullness. While it does not detract from such particularity, it does privilege commonality as ultimately more fundamental than particularity. This, in turn, raises the question of what it is that can be inspiring and what kind of teaching can be communicated across religions. Meir Sendor's contribution in this volume, reviewing the Religious Genius project, raises this issue in the context of Judaism, with particular reference to the Ari, Rabbi Yitzchak Luria Ashkenazi, considered by many to be the greatest of the kabbalists. Can the Ari's teachings be communicated outside Judaism, and if not, is it only the particularity and density of his theosophy or is there something that is fundamentally incommunicable across religions? Even if there is, is there another dimension that is communicable notwithstanding the untranslatable aspect of the teaching? And how are we to weigh the relationship between these two dimensions as we appreciate a figure in his or her full complexity. I am grateful to Sendor for posing some of these questions from the perspective of the particularity of Jewish tradition and how it might be receptive to the theory of Religious Genius. They touch on core challenges of viewing Judaism from a coevolutionary perspective.

The complement volume to Religious Genius is Luther the Anti-Semite: A Contemporary Jewish Perspective (Goshen-Gottstein 2018b). This work, written in the context of the 500th anniversary of the Reformation, seeks to chart a new course in the muddy waters of what is known as the problem of "Luther and the Jews." Scores of publications have analyzed Luther's complex, and largely negative, view of Jews, leading to his eventually serving as inspiration for Third Reich ideologues. Lutheran churches have had to undergo a process of introspection and purification, resulting in multiple apologies for Luther's positions on the Jews. Jews on the whole have either distanced themselves from Luther on those grounds or have had serious reservations regarding this important figure in religious history. From this perspective, Luther is the antithesis of a Religious Genius, even if some might argue that in other dimensions he was a Religious Genius. In fact, Luther was an example of what we in the Religious Genius project referred to as a "flawed Religious Genius." This book revisits Luther's antisemitism, expressing a coevolutionary view of Judaism not only in relation to the most inspiring instances of religious history but also in relation to some of the most terrible behavior carried out in the domain of religion, specifically targeted at Jews. It asks what went wrong with Luther's teaching, a question that can be posed precisely because there are stages in Luther's views on the Jews. We must therefore account for why he shifted from what might be presented as a positive view to the later full rejection of Jews and the series of destructive recommendations he issued. To account for that, I have brought together various insights found in the literature regarding what drove Luther in his theological work and, specifically, what factors influenced his negative view of the Jews. These were assembled 
into a model, the "Luther Model" - a negative model serving as a counterpart to the positive model of "Religious Genius." Once the model is constructed, one can shift attention from Luther the person and his abhorrent teachings and recommendations on the Jews, to the model and what it teaches us about what can go wrong in religion. In this move, Luther serves as a teacher of what can go wrong, and his negative example can speak across religious lines to Jews as well as to other situations of interreligious enmity. The final part of the book examines the various components of the "Luther Model" and suggests that these can actually be found today, to some extent, in attitudes of some Jewish practitioners (albeit a minority) toward Christians.

The coevolutionary perspective allows us, then, to move from condemnation to learning, from study of the other to self-introspection, and from the victim's position to that of the aspirant who seeks to advance individually and communally in line with lessons learned from other religions and from examples found therein, whether they be the best or the worst of religion.

\section{Collaborative Interreligious Projects}

Much like the birth of "Religious Genius," a series of projects under my leadership and eventual editing brings together scholars and thinkers of multiple religions (Judaism, Christianity, Islam, Hinduism, Buddhism, and Sikhism) to work through issues that are of significance for interreligious theory. A series titled "Interreligious Reflections," initially published by Lexington Books and later rehoused in Wipf and Stock publishers, shares the fruits of these collaborative think-tank projects. My role as convener and editor in this series is very active. While each project seeks to explore some aspect that is fundamental to the theory of interreligious relations, the choice of themes and the overall approach does, at least from the editor's perspective, subscribe to a coevolutionary view of religions. The scholars that these projects bring together seek to grow together in mutual understanding and in jointly tackling present-day challenges. In the process, strategies are shared across religions and resources are developed in interdependent inspiration. The entire enterprise is an opportunity for growth within each of the traditions, as well as in the space created by their coming together, as they think in a collaborative manner and share strategies, perspective, wisdom, and inspiration.

One of the pairs, within a series of six, is indeed devoted to the theme of "sharing." The volume titled Sharing Wisdom: Benefits and Boundaries of Interreligious Learning (Goshen-Gottstein 2016b) goes to the heart of the process of sharing and explores its parameters and possibilities as well as its pitfalls and limits. Much as Religious Genius assumed the possibility of inspiration across religions, this volume too assumes the possibility of sharing wisdom across traditions. But wisdom must be shared wisely. The scholars explore different dimensions of how the sharing of wisdom is particular to each of the traditions and how sharing wisdom may nevertheless be undertaken as a common enterprise, despite such particularities as the Christian identification of Jesus with wisdom. In the present volume, Yehuda Gellman takes the discussion further by considering how wisdom is related to concerns 
of truth and what kinds of wisdom might be shared in full and in part, especially in view of truth claims and other specific faith commitments. His analysis advances the exploration of how the particularity of each tradition may be related to broader universals and of the mechanisms of translating or appreciating the wisdom of the particular in the other religion.

Another kind of sharing is profiled in Friendship Across Religions: Theological Perspectives on Interreligious Friendship (Goshen-Gottstein 2015a). Just as a notion of sharing wisdom across religions has to be constructed, so too interreligious friendship is a notion that is novel, at least conceptually, to all traditions. It has to be argued for, precedent has to be sought, and parameters and conditions for it must be established. The challenge of justifying friendship across religions is even more acute when we consider friendship not just a matter of neighborly courtesy but an occasion for spiritual exchange. The volume's challenge is whether one can have the deep spiritual intimacy that friendship provides with a believer of another faith. Beyond issues of permissible and non-permissible is the issue of what is possible in terms of personal and spiritual sharing across religions and how they come together in the experience of interreligious friendship. This is an important instance of spiritual growth that can occur as part of joint interreligious reflection. The challenge and opportunity that inform this volume only arise in situations of interreligious contact. In authoring the lead Jewish essay in this collection, I was hard-pressed to find a historical precedent that could legitimate interreligious friendship. Theological reflection, collaborative problem-solving, mutual inspiration, and the broader interreligious reality are the context for advancing thought on a novel spiritual possibility. As multiple religions struggle with the same challenge, they coevolve.

The next pair of books in the series goes to the root of problems in relations between religions and their adherents and seeks to offer solutions and approaches to those challenges. The first project in this series was The Religious Other: Hostility, Hospitality and the Hope of Human Flourishing (Goshen-Gottstein 2014b). The starting point is that religious hostility exists and that tackling it is not just a matter of policy but requires religious thought, teaching, and constructive theology. It explores the theological resources available in each of five traditions for moving from hostility to hospitality. Here, hospitality means not only the kind of practical hospitality one would offer the wayfarer but also theological hospitality and receptivity to ideas, or to the best of other faiths. These, in turn, are dependent on a broader view of ideal life, ideal society, and the vision of human flourishing, comprising the third component in the book's subtitle. Some of the concerns of this project overlap with Sharing Wisdom, but significant attention is devoted to tackling and diffusing the "problematic" parts of tradition, those teachings that are still part of Scripture and often condition attitudes of believers, which would get in the way of cultivating positive appreciation for others. This points to an important part of the work, collaborative as well as carried out purely from a Jewish perspective. Advances in interreligious relations place before us novel theoretical challenges and opportunities. If a vision is set forth for the sake of our communities, it is not sufficient to simply offer a positive view, possibly citing scriptural references. One must also confront and either contextualize, neutralize, or otherwise interpret texts, concepts, and portions of traditions that have for centuries fed attitudes that hamper 
the kind of growth presented here as coevolution. Evolution is itself a process of struggle and confrontation against opposing forces, and coevolution of religions, in this understanding, is not only the constructive tension of exchange of ideas and their beneficial inspiration within religions but also the joint confrontation that all religions must undertake in reframing interreligious relations and establishing new paradigms.

"Co" in coevolution could remain a superimposed conceptual structure by means of which historical and religious data are interpreted. However, affirming commonality and overcoming separateness is a practical agenda that goes to the heart of interreligious dialogue. This is closely related to philosophical reflections on the notion of otherness and how it is to be constructed, or overcome. Steven Kepnes's essay in response to The Religious Other tackles the very notion of otherness, both as articulated in essays under review and as expounded by modern Jewish philosophers. Reading Kepnes in the context of the present essay makes me aware of how crucial confronting the notion of otherness is for a robust understanding of coevolution.

A further example of collaborative confrontation of common challenges is the second volume in this pair: Memory and Hope: Forgiveness, Healing and Interfaith Relations (Goshen-Gottstein 2015c). Religious communities are, on the whole, traditional-faithful to their foundational memory as well as to the memory of key moments in their history. This includes also interreligious relations and especially the hurt that different religions have suffered in their relationship. The pain of yesteryear continues to feed the religious competition and negativity of today. If religions are to advance, they must advance past the pain of memories to which they cling. Memories must be healed. The challenge is common, and this volume explores what each of the traditions brings to the task of healing memory and how religions might share with one another strategies for purifying, healing, or otherwise dealing with the potentially destructive legacy of painful historical memories. It is, then, an expression of sharing wisdom, focused on a common challenge that goes to the heart of interfaith relations, tying past and present, seeking to move religions beyond where they are "stuck" and to open up new horizons of hope between religions.

It is not irrelevant to mention here the most recent project of the Elijah think tank that has been presented to the Elijah Board of World Religious Leaders. ${ }^{5}$ Perhaps even more importantly than memory, concerns for identity feed interreligious competition and often account for negativity between faiths. Identity is essential. But how can it be upheld in ways that do not limit advances in interfaith understanding? The most recent project explores "Identity and Mysticism" as a pair and considers whether mysticism holds a promise for neutralizing parts of religious identity that owe more to human needs than to the divine mandate and foundations of the religions.

The third pair of collaborative studies features commonality and collaboration from another perspective. Two volumes are devoted to how world religions tackle

\footnotetext{
5 All volumes in the Interreligious Reflections series have their genesis in a collaborative think tank undertaken in preparation for meetings of a premier group of world religious leaders associated with the Elijah Interfaith Institute. This project served the 8th biennial meeting in 2018.
} 
common challenges. Judaism's voice blends with that of other religions in order to form a composite picture of the challenges that religion and religious leadership face today. The first volume is The Crisis of the Holy: Challenges and Transformations in World Religions (Goshen-Gottstein 2014a. The project reflected in this volume considers that all religions are threatened, challenged, and face a common crisis. The shared crisis assumes a fundamental commonality, irrespective of beliefs and practices of individual religions. A range of contemporary threats or perceived threats, from the challenges of technology to the status of women and youth, and many others, is representative of the time, and these are challenges that no religion can avoid. Recognition of the commonality of these contemporary challenges opens the way to sharing strategies for how to cope with them. The Crisis of the Holy was developed with religious leaders as its first intended audience for the second meeting of the Elijah Board of World Religious Leaders. Seeing the larger picture, involving all world religions, provides leaders with a broader perspective that could potentially allow solutions and ways of handling the challenges to emerge. Such a perspective is offered in the book's conclusion, where identity provides one pole and spirituality provides the other pole, on an axis by means of which the volume's subject matter is analyzed. The latest project on "Identity and Mysticism" picks up on the thematic tensions already identified in this earlier work.

Shlomo Fischer's essay, building on The Crisis of the Holy, is a fine illustration of how the crisis is not simply a sociological reality but can be appreciated within the coevolutionary perspective described here. His appeal to Rav Kook as a theoretical framework for appreciating the crisis, a crisis already addressed consciously by Rav Kook himself, enhances the view of the crises and changes that religions undergo as stages in their own purposeful evolution.

The other volume in the series that addresses contemporary challenges is The Future of Religious Leadership: World Religions in Conversation (Goshen-Gottstein 2016a). The volume studies how leadership is understood and practiced across religions, a subject fitting for self-reflection among a group of premier world religious leaders. Its conclusion is significant for the present issue of Contemporary Jewry. Probably more than any other subject, the project points, or so its editor considers, to the fundamental commonality in the practice of leadership across religions. No matter how different the theology of leadership is nor its originary founder who serves as inspiration and reference point, the actual understanding and operation of leadership across religions is so close that it allowed me to conclude the volume with a common prayer that could be recited with equal comfort by leaders belonging to diverse religions. This prayer has in fact been used since in various circles, offering further evidence for the fundamental similarities in how leadership functions across religions. Hanoch Ben Pazi, in the present volume, drives home the point underlying this book in a way I myself might not have stated when I undertook this project: For religious leadership today to be effective, it must be interreligious. I hesitate to put the matter as strongly as he does. However, the recognition that the fullness of our religious understanding, today more than ever, involves us in an understanding of how our religions operate in concert, in dialogue, and in a coevolutionary process with other religions turns out to be the thread running through my work. The study of religious leadership, then, provides a very appropriate case in point. 


\section{Jewish Theology of Religions}

A substantial part of my work has focused on a Jewish view of other religions. I would like to make the argument here, or offer the reading, that my own work in Jewish theology of religions fits within the coevolutionary paradigm, wherein a Jewish view must be appreciated as part of processes affecting all religions. There are several ways in which my work contributes to such an argument.

A. Like other religions, Judaism too must revisit its attitudes toward other religions in a more accommodating manner that is commensurate with advances in interfaith religions and the spirit of the day.

B. The key concern of a Jewish theology of religions (unlike a Christian theology of religions) is establishing the legitimacy of another religion. Establishing legitimacy would seem to be a precondition for many of the proposed moves presented above-thinking collaboratively, receiving wisdom, being inspired by the finest exemplars of another tradition, and more. If a religion lacks all legitimacy, it is hard to make these moves in relation to it. Indeed, one of the main obstacles to these attitudes not having taken hold previously or not having taken hold in certain Jewish societies was the lack of legitimacy associated with other religions. Once we establish another religion's legitimacy, the path is open to consider how both Judaism and the other religion can be considered as species of a genus (another biological metaphor), with all the potential benefits such recognition carries for the religions and for their adherents.

C. Traditionally, a Jewish view of other religions has resorted to key ideas by means of which Judaism was distinguished from other religions, such as the notion of truth being reserved for Judaism or the designation of other religions as idolatrous. A view of Judaism within world religions leads us to revisit some prior assumptions of where the fault lines lie and whether they indeed lie between one religion and another. The suggestion for this alternative line of thinking is that those notions that have served to distinguish Judaism and world religions are actually categories by means of which we discern higher and lower forms of the religious life, and these can be found in all religions. Religions thus share the common challenge of advancing their understanding and the understanding of believers in line with the highest ideals, which are realized in part and remain unrealized in part in all religions. Just as the task of tackling practical challenges is one in which religions can share, so too the challenges relating to religions' spiritual evolution and understanding are also common to religions.

The first book devoted to a Jewish theology of religions was the volume of essays co-edited with Eugene Korn, Jewish Theology and World Religions (Goshen-Gottstein and Korn 2012). The volume sought to develop a conversation among Jewish thinkers and scholars on the very issues that a Jewish theology of religions should tackle. In its introduction, it was stated that Judaism too must undertake a process of theological reflection on other religions, akin to the efforts made by the Catholic Church during the Second Vatican Council. The volume thus consciously positioned Judaism as part of larger processes taking place in other religions. These amount to an invitation to Judaism and to other religions to follow suit. The volume identified some of the basic challenges to a contemporary Jewish theology 
of religions, many of which are in fact obstacles to be removed or notions to be rethought if we seek to position Judaism among world religions. Some of the essays in the volume also discussed ways in which inspiration and contact could be developed between religions, thereby further contributing to the fundamental orientation described here. Ephraim Meir's essay, in dialogue with this book, presents what he calls "dialogical theology," by means of which he seeks to develop a conceptual framework that would justify learning from other religions and overcoming a narrow definition of religious truth. He thereby reinforces many of the voices featured in Jewish Theology and World Religions, in fact pointing them in the same direction as the present coevolutionary reading does.

A second volume that has not yet been submitted for publication is tentatively titled Heschel, Greenberg, Sacks: Jewish Thinkers Face World Religions. This volume focuses on the views of three leading Jewish thinkers, considering their thought in light of the conceptual matrix created in Jewish Theology and World Religions. The parts of this upcoming publication that have been published form the basis for Eugene Korn's essay in the present volume. ${ }^{6}$

The issue of recognition of another religion, its validation, and the ensuing possibilities for learning, receiving, and growing through the encounter with that religion are the focus of the twin volumes on Judaism and Hinduism, The Jewish Encounter with Hinduism: Wisdom, Spirituality, Identity (Goshen-Gottstein 2015b) and Same God, Other god: Judaism, Hinduism and the Problem of Idolatry (Goshen-Gottstein 2015d). Almost all the theoretical challenges and possibilities that arise in the context of a Jewish view of and encounter with another religion come to expression in the study of the Jewish encounter with and a possible Jewish view of Hinduism. The challenge of legitimation occurs at the most fundamental level: Is Hinduism a legitimate religion or does it constitute avoda zara, idolatry? The possibilities for mutual growth and inspiration are studied through the many angles of the contemporary and unprecedented encounter in which a massive number of young Israelis follow in the footsteps of American and European Jewish youth decades earlier exploring the spiritual riches of India. Once again, we encounter the two poles of identity and spirituality. Jewish identity is threatened by encounter with another religion at the same time as new spiritual openings arise. These new spiritual openings come to light for practitioners, but even more significantly for Jewish thought and Jewish tradition, as they encounter a new and significant conversation partner in the form of Hindu thought. In the same way that Judaism has grown throughout the centuries in its encounter with other traditions and civilizations, so too this new religious encounter opens up multiple possibilities for revisiting many lost parts of Jewish tradition and gaining fresh perspectives on the fundamentals of a religious view of reality and of Judaism's position in relation to world religions. These two volumes are not discussed in the present issue of Contemporary Jewry. For reasons of space, it has been decided to dedicate a separate issue to Judaism and its encounter with Hinduism. For purposes of an overview of my work, these two volumes put into practice the theoretical assumptions that inform much of my work.

\footnotetext{
${ }^{6}$ See Goshen-Gottstein $(2007,2009,2018$ a) for the parts of this publication that have already been published.
} 
Some of these will be spelled out presently with reference to the Meiri. More broadly, the move from (possibly) legitimating another religion to the sharing of wisdom, in an interdependent process of growth, is illustrated with reference to this one particular relationship.

Two upcoming volumes explore how our theological categories, or the notions that are central to our theology of religions, should be, or could be, revisited in light of advances in Jewish theology of religions and the present Jewish encounter with other religions. Religious Truth: Essays in Jewish Theology of Religions (Goshen-Gottstein 2020 b explores what religious truth means as it relates to Judaism and world religions. The different essays seek to balance a simplistic view of religious truth with a more universal approach, one that nuances and problematizes what we mean by the term "truth" and allows us to reconceive the facile distinction of truth and falsehood as corresponding to Judaism and other religions. One possible, and in my view very significant, model that arises is that truth is a dimension of all religions. Not all expressions of a religion rise to its highest truth, and complementing that there is no religion, at least not among the world's great religions today, that is devoid of that dimension of spiritual cognition and existential being that we refer to as truth. If so, truth is a dimension of religion that cuts across all religions, distinguishing their higher and lower forms, rather than a means of identifying one religion compared with another. One of the arguments that is put forth is that universalism is broader than a Jewish teaching meant for the world at large. God is known through multiple channels, thereby taking truth outside the exclusive realm of Israel. This argument can be developed within a coevolutionary view of truth as different means and dimensions through which God is known mutually support and enhance one another.

Complementing this is a volume devoted to the question of avoda zara, idolatry (Goshen-Gottstein forthcoming). Here too, I seek to develop a conversation among Jewish thinkers on the meaning of avoda zara as a category internal to Jewish thought, its language and its concerns. This project grows out of my work in Same God, Other god (2015d), where the notion of idolatry was queried and nuanced, including the possibility of avoda zara serving as an internal category (by no means an original insight). The theological challenge is not simply to clear other religions from the charge of avoda zara. If we are to retain the category (must we?), we must also answer the question of what is it that makes something avoda zara and what the problem with it is. To do this, we must be able to shift our attention from its uses with reference to other religions to its possible internal uses. It is quite a challenge to identify wherein lies avoda zara today. This challenge grows directly from the possibilities opened up by the encounter with other religions and is one example of the internal spiritual and theological benefits that we derive from developing Jewish theology of religions as an indispensable part of any Jewish theological reflection.

\section{Jewish Particularity and Universality}

One of the most celebrated dichotomies by means of which Jewish tradition is viewed is the tension between particularity and universality. Typically, one thinks of Judaism either as it affirms its uniqueness, which often leads it to focus inwards 
and to ignore others, even cultivating a kind of theological hostility toward other religions, or as it delivers a universal message. Jewish universality is most typically considered from the perspective of the Jewish message to the world and of what is Judaism's mission. Another dimension of universality is Judaism's care for the entire world and all of creation, leading to constructive action such as through the celebrated notion of tikkun olam.

Coevolution goes to the heart of the tension of particularity and universality. It makes the fundamental assumption that "no religion is an island," to cite title of Abraham Jacob Heschel's celebrated essay (https://utsnyc.edu/wp-content/uploads/ Heschels-No-Religion-is-an-Island.pdf), and consequently that all religions interact and grow together. A coevolutionary perspective assumes that growth is a process commonly and mutually undertaken. While in theory a coevolutionary perspective can be upheld even if other religions are rejected, ${ }^{7}$ a healthy recognition of coevolution must assume a great degree of legitimacy of another religion. Such a perspective assumes that Judaism itself must grow and that its growth is in some way indebted and related to other religions. The facile distinction of Judaism as the giver and other religions, or all of humanity, as the receiver is thereby undermined.

How coevolution opens up a new chapter of Jewish universality touches on a fundamental challenge of a contemporary Jewish theology of religions-understanding Jewish election. Election is one of the biggest challenges for any Jewish theology of religions. What comprises Jewish uniqueness, what uniqueness means for a Jewish view of other religions, and what practical consequences and the limitations, as well as opportunities, uniqueness places upon relations with other religions are issues that have informed the history of Jewish relations with other religions and peoples for millennia. These issues must be revisited within the framework of a contemporary Jewish theology of religions. This task is taken up in a volume titled Judaism's Challenge: Election, Divine Love and Human Enmity (Goshen-Gottstein 2020a). This too is a collaborative project, a conversation I have sought to develop in view of the importance of this theoretical challenge. Contributions in this volume range from tackling the inherited negativity that characterizes some Jewish attitudes toward others-be it other religions or other peoples - to ways of articulating the meaning of Jewish election so that it remains open to collaboration with world religions. The essays present the vast range of possible understandings of how Judaism views those outside, including models for viewing other religions. While the volume does not reach one specific conclusion, an impossibility in and of itself, it does suggest that Jewish election does not stand, of necessity, in the way of advancing a Jewish theology of religions. From the perspective of the present essay, one may argue that even Jewish election must be appreciated within a coevolutionary perspective. Such a perspective need not assume full equality and reciprocity, and it can be reconciled with hierarchy, even as it is appreciated from a Jewish coevolutionary perspective.

\footnotetext{
7 See Rav Kook (1999), Shmona Kevazim, 5,91. Rav Kook extends a coevolutionary understanding even to forms of religion that he considers evil.
} 


\section{Theoretical Moorings: The Meiri and the Same God Question}

Over the course of my work, I have appealed to many resources. One in particular stands out for me as I seek to offer a reading of my work to date. This is the work of the 13th-century Rabbi Menachem Hameiri. Meiri's work is referenced throughout my writings and is discussed in great detail in Same God, Other god (2015d). Meiri developed a position according to which all contemporary religions are legitimate. Their legitimacy affords them the status of "religion," meaning legitimate religions that do what religions are meant to do-help advance the lives of individuals and society at large, morally and spiritually. For Meiri, idolatry was a thing of the past, at best a remote possibility with which one need not be concerned. Issues of truth were also relegated to a secondary place, following an attempt to go to the heart of what makes religion important. That which makes religion important-fundamentals of the moral life, opportunities for the spiritual life, and a basic understanding of God-are common to all religions. Even if Judaism has an advantage over other religions in terms of the correctness of its teachings, in terms of the functioning of religion as a "religion," Judaism is one in a family of many religions. The flip side of the recognition of other religions as legitimate, as "religions," is the implied commonality of Judaism and other religions. Meiri himself did not dwell on those implications, given his time and place. His teachings provide a foundation for us to revisit the implications of his theology of religions to a broader view of how Judaism relates to world religions. Meiri's views are informed by a theory of progress, one of evolution of religions. This evolutionary drive, coupled with the recognition of the centrality of the notion of "religion," make Meiri an essential frame of reference for me as I seek to develop not only a positive contemporary Jewish theology of religions but as I apply it to a broader coevolutionary view of Judaism and other religions.

Complementing the recognition of other religions as legitimate is the move of affirming the God of another religion as the same God. A "same God" strategy moves the discussion beyond previous discussions of idolatry and its applicability and seeks the foundational commonality that lies beyond apparent diversity of faith and worship practices. If another religion is legitimate, then ultimately it must point to the same God, even if this is not apparent on first view. This is one of the most interesting challenges of a contemporary Jewish view of other religions, growing as it does out of Meiri's theoretical foundations. Once we establish criteria for legitimacy and move the discussion to how we might know that the God worshipped in two religions is the same God, an entire field of learning opens up to us. This allows us to advance a conversation with another religion that is characterized by nuance, understanding, mutual enrichment, and inspiration. This is the kind of conversation I have aimed for in many of my works, books, and articles, and I believe it will continue to challenge me, and others, in years to come.

\section{References}

Bianchi, Robert R. 2019. China and the Islamic world: How the new Silk Road is transforming global politics. New York: Oxford University Press.

Boyarin, Daniel. 2004. Border lines: The partition of Judaeo-Christianity. Philadelphia: University of Pennsylvania Press. 
Burton, Lloyd. 2002. Worship and wilderness: Culture, religion, and law in public lands management. Madison: University of Wisconsin Press.

Burton, Lloyd. 2005. Author's response: Worship, wilderness, and cultural coevolution. Law and Society Review 39(3): 711-722.

Cherry, Shai. 2003. Abraham Isaac Kook on evolution: How evolutionary theory supports a mystical worldview. My Jewish learning. https://www.myjewishlearning.com/article/abraham-isaac-kook-on-evolu tion. Accessed 14 March 2020.

Coevolution. n.d. Nature.com. https://www.nature.com/subjects/coevolution. Accessed 14 March 2020.

Ehrlich, Paul R. 1986. Coevolution and the biology of communities. In News that stayed news, 1974-1984: Ten years of coevolution quarterly, ed. Art Kleiner and Stewart Brand, 3-9. San Francisco: North Point Press.

Feit, Carl. 2006. Modern Orthodoxy and evolution: The models of Rabbi J. B. Soloveitchik and Rabbi A. I. Kook. In Jewish tradition and the challenge of Darwinism, ed. Geoffrey Cantor and Marc Swetlitz, 208-224. Chicago: Chicago University Press.

Goshen-Gottstein, Alon. 2007. No religion Is an island: Following the trail blazer. Shofar 26(1 (Fall)): 72-111.

Goshen-Gottstein, Alon. 2009. Heschel and interreligious dialogue: Formulating the questions. In Abraham Joshua Heschel: Philosophy, theology and interreligious dialogue, ed. Stanislaw Krajewski and Adam Lipszyc, 161-167. Wiesbaden: Harrassowitz.

Goshen-Gottstein, Alon (ed.). 2014a. The crisis of the holy: Challenges and transformations in world religions. Interreligious reflections. Lanham: Lexington Books.

Goshen-Gottstein, Alon (ed.). 2014b. The religious other: Hostility, hospitality and the hope of human flourishing. Interreligious reflections. Lanham: Lexington Books.

Goshen-Gottstein, Alon (ed.). 2015a. Friendship across religions: Theological perspectives on interreligious friendship. Interreligious reflections. Lanham: Lexington Books.

Goshen-Gottstein, Alon. 2015b. The Jewish encounter with Hinduism: Wisdom, spirituality, identity. New York: Palgrave Macmillan.

Goshen-Gottstein, Alon (ed.). 2015c. Memory and hope: Forgiveness, healing and interfaith relations. Interreligious reflections. Lanham: Lexington Books.

Goshen-Gottstein, Alon. 2015d. Same God, other god: Judaism, Hinduism, and the problem of idolatry. New York: Palgrave Macmillan.

Goshen-Gottstein, Alon (ed.). 2016a. The future of religious leadership: World religions in conversation. Interreligious reflections. Lanham: Lexington Books.

Goshen-Gottstein, Alon (ed.). 2016b. Sharing wisdom: Benefits and boundaries of interreligious learning. Interreligious reflections. Lanham: Lexington Books.

Goshen-Gottstein, Alon. 2017. Religious genius: Appreciating inspiring individuals across traditions. New York: Palgrave Macmillan.

Goshen-Gottstein, Alon. 2018a. Genius Theologian, Lonely Theologian: Yitz Greenberg on Christianity. In A Torah giant: The intellectual legacy of Rabbi Dr Irving (Yitz) Greenberg, ed. Shmuly Yanklowitz, 71-92. Jerusalem: Urim Publishing.

Goshen-Gottstein, Alon. 2018b. Luther the anti-Semite: A contemporary Jewish perspective. Minneapolis: Fortress Press.

Goshen-Gottstein, Alon (ed.). 2020a. Judaism's challenge: Election, divine love and human enmity. Boston: Academic Studies Press.

Goshen-Gottstein, Alon (ed.). 2020b. Religious truth: Towards a Jewish theology of religions. Oxford: The Littman Library of Jewish Civilization.

Goshen-Gottstein, Alon (ed.). forthcoming. Idolatry-A contemporary Jewish conversation. Boston: Academic Studies Press.

Goshen-Gottstein, Alon, and Eugene Korn (eds.). 2012. Jewish theology and world religions. Oxford: Littman Library of Jewish Civilization.

Kook, Rabbi Avraham Isaac. 1999. Shmonah Kvatzim. Available at https://www.sefaria.org/Shmonah_Kvatz im?lang=bi.

Menchik, Jeremy. 2016. Islam and democracy in Indonesia: Tolerance without liberalism. New York: Cambridge University Press.

Valeur, Henrik. 2014. India: The urban transition-A case study of development urbanism. Copenhagen: The Architectural Publisher B. 
Publisher's Note Springer Nature remains neutral with regard to jurisdictional claims in published maps and institutional affiliations.

Alon Goshen-Gottstein is a scholar of rabbinic thought, theoretician of interfaith relations and theology of religions, and an interfaith activist, whose particular contribution to the field of interfaith consists of bringing together scholars and religious leaders for study, reflection and advancing interpersonal and intergroup relations. He is founder and director of the Elijah Interfaith Institute (formerly the Elijah School for the Study of Wisdom in World Religions) since 1997. 